\title{
Analysis of Library Management Information System in Muhammadiyah 2 Vocational High School, Malang
}

\section{Sri Nastiti Andharini, Novi Puji Lestari, Novita Ratna Satiti, and Kenny Roz}

Management Departement at University of Muhammadiyah Malang

\section{Abstract}

Management Information Systems as a computer-based system that provides information for several users who have similar needs. Information explains the company or one of its main systems about what has happened in the past, what happened now and what happened in the future. This study aims to analyze the problems in the library of Muhammadiyah 2 Vocational High School Malang which has many departments including multimedia, accounting, office administration and computers. This study is the result of a case study research that searches data using secondary data.

Keywords: information system, library, secondary school
Corresponding Author: Novi Puji Lestari novilestari@umm.ac.id

Received: 10 February 2019 Accepted: 14 March 2019 Published: 28 March 2019 Publishing services provided by Knowledge E

(c) Sri Nastiti Andharini et al. This article is distributed under the terms of the Creative Commons Attribution License, which permits unrestricted use and redistribution provided that the original author and source are credited.

Selection and Peer-review unde the responsibility of the ICIEBP Conference Committee.

\section{G OPEN ACCESS}

\section{Introduction}

Knowledge is not only acquired from the real experience, but also from accepted information. The information is available on various media, such as a library with a variety of books. This is in accordance with the function of the library as a platform of storage, management, service, dissemination, and maintenance of the knowledge.

Library as an information and knowledge administrator should utilize the use of information technology optimally by fulfilling various needs. There are several considerations of the reason on why library must utilize the use of information and communication technology due to the demand on (1) quantity and library services; (2) item collection use simultaneously; (3) human resource needs; (4) time efficiency; and (5) various information management.

Learning is an activity involving an individual effort to acquire the knowledge, skill, and positive values by utilizing various learning sources effectively. Therefore, learning activity highly depends on learning sources. Its existence will ease the students in obtaining information and knowledge based on their needs. Moreover, the students can discover the knowledge outside school activity. 
The students also can utilize learning sources in the environment, such as learning natural sciences both plant and animal. In the development of era, science, and technology, learning source allows the students to learn individually but parental guidance is still needed.

The development of technology is expected to positively contribute to the educational organization. It will ease the work of human effectively and efficiently. One of technology development is a computer. It aims at facilitating an individual works running at the same time effectively.

The excellence of the computer is fast, accurate, and efficient in processing the data rather than other manual systems. The computer has been developing in every sector, such as working environment, education, economics, etc. This development has created a competition among the schools to establish educational systems-based technology. Therefore, the development of computer application must be followed up by the administrator of education institutions.

Vocational School is one of the educational products with various departments, such as Multimedia, Office Administration, Marketing, and Accounting. However, many senior high schools have implemented yet information system-based in the learning process, for example in the library. It occurred due to a manual system is still implemented till now. This situation leads to ineffective registration and technical errors in searching the data, such as borrowing and returning books. Hence, the use of a computer application system would ease the administrator in displaying data information and library rapidly, accurately, and properly.

Barcode Scanner is one of a smart device in scanning the books in the library. This device just needs PHP (Hypertext Preprocessor) and MySQL (My Structured Query Language) software in the computer to assist the performance.

\subsection{Statement of the problems}

Based on phenomena above, the researcher would like to investigate the following problems, namely:

1. The optimality of data processing is still conducted manually without a computerbased system in organizing the data of borrowing and returning books which leads to the lack of accuracy, effectiveness, and efficiency on time period.

2. Data corruption is a main problem in the school library.

3. The data report and inventory are not computerized yet. 
4. The absence of an online system leads to students' inability to access information anytime and anywhere.

\subsection{Purpose of the study}

1. To examine the systems of the library at SMK Muhammadiyah 2 Malang.

2. To solve library problems at SMK Muhammadiyah 2 Malang.

\subsection{Significance of the study}

\section{School}

The results of the study are expected to provide a solution as a consideration in making a decision related to library management.

\section{Further study}

The results of the study stand for a consideration and information related to library management.

\subsection{Limitation of the study}

The limitation aims at focusing on the problem and solution. Hence, the limitation is the problems faced by the library at SMK Muhammadiyah 2 Malang.

\section{Reference}

\subsection{Previous study}

As a study on website-based library systems at SMA Negeri I Ngaglik Yogyakarta conducted by Pramana (2013), is aimed at designing a good website-based library system resulting in database systems is running well.

Sulastri (2013) examined that an online information system can ease the administrator to process the data of the library which conducted at SMP Negeri 4 Surakarta.

\section{Theoretical Review}




\subsection{System}

The concept of systems works in every aspect of life, such as education, culture, economics, politics, etc. The system is a set of components which relates to a clear limitation to reach an achievement by producing organized transformation (Brien, 2014:27). There are numerous examples of the system, such as physical and biophysical sciences from the sun and planets; a biological system of the human body; technology system of oil refining; and organization of a business. The system has three basic functions, namely:

1. Input involves stimulus into a system to be processed. For instance, raw material, energy, data, and human should be secured and organized for a better management.

2. Processing involves the process of transformation by converting an input to be an output. For instance, in the manufacturing process, the human respiratory system, or mathematics calculation.

3. Output involves the transfer of elements which results in a transformation process as the final purpose. For instance, finished goods, service, and information management.

Information system comprises reciprocal components; those are people, software, hardware, and network resources.

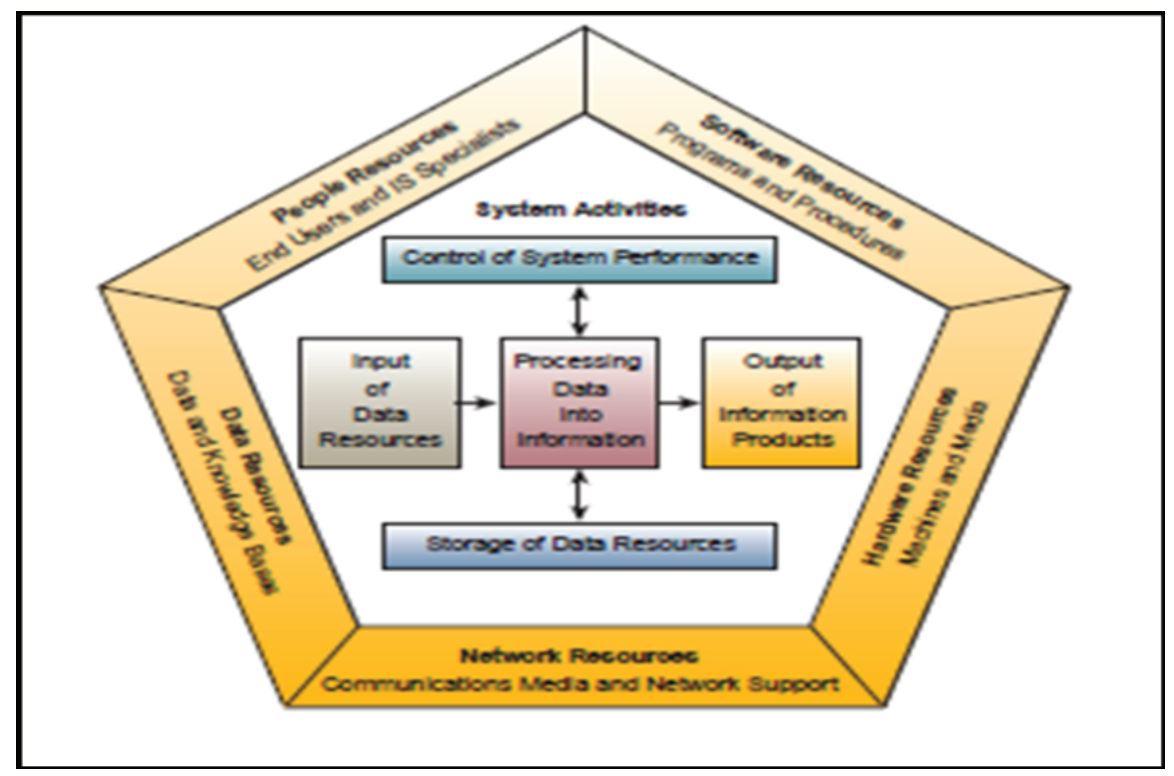

Figure 1: Components of an information system. 


\subsubsection{Information}

According to James O Brion (2010), a management information system is a computerbased system which provides information and needs to the users. The information explains the working patterns of the company in the past, present, and future events. Moreover, Kennedy (2014) defined it as an integrated system between human and machine in giving information to assist the operation, management, and decision making in an organization.

Based on the Encyclopedia of Management, a management information system is an organized approach aimed at assisting the expert to conduct a managerial process to the leaderboard. The information system model emphasizes the relationship between component and activity. There are four main concepts of information system component, namely people, hardware, software, and network resources. Human resources accommodate the specialist and user of the information system; hardware resources consist of machine and media, and software resources involve the program and procedure.

\subsubsection{Database}

The database is an integrated collection of data element which is logic. It consolidates previous record storage in separated archives into data group by providing various applications. Thus, the database contains data element describing the relationship between entities. In the following discussion, there is a picture that describes the relationship of entities in the database for an electrical utility.

Database management system (DBMS) is software which allows the users to control and access the data practically and efficiently. DBMS can be used to accommodate the various needs of the users. Commonly, it provides many features which are accessible, safe, fast, and easy. The implementation of DBMS language is varied according to the company design. Mainly, the language is categorized into three components of data definition language, namely (1) an instruction to create new table with the same type and length (CREATE); (2) an instruction to convert the index to be compiled data (INDEX, REINDEX); and (3) an instruction to convert the structure from data files (MODIFY STRUCT). These components are commonly used by the administrator of the database in compiling the data. DML is language component of DBMS which aims at manipulating the data. Data Manipulation Language differs from two types, namely DML Procedural and DML Non-procedural. 


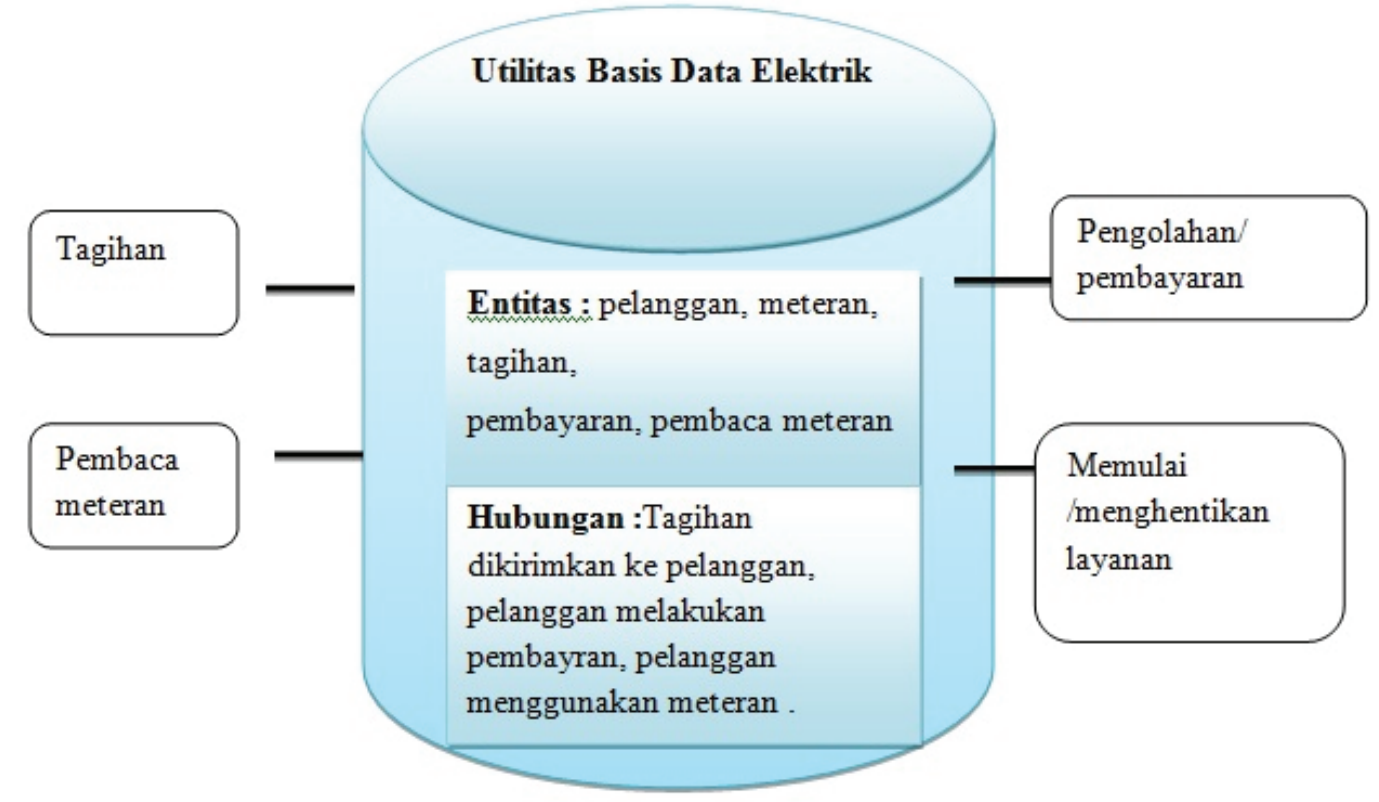

Figure 2: The relationship of entities in the database (Source: James O'Brien in Information Technology (Page 192)).

DML Non-procedural data can be manipulated directly without an instruction of how the data are read from the file. The instruction of DML Non-procedural data is commonly used in DBMS languages, such as dBase, Access, Paradox, FoxPro, SQL, etc. Data Control Media Language is a kind of DBMS language component used by the operators of the database in organizing the data physically. The instruction consists of recording (Write Record, Create Table) and deleting (Drop, Delete Table). The library is a part of learning sources that should be owned by a school or higher education. The existence of technology development, the students easily search the information and knowledge wherever and whenever. By utilizing website networking, the system will simply convert conventional approach to computerized approach, for example, library management.

\subsubsection{Information technology}

The existence of an organization or company is determined by a long-term strategy to encounter five competitive powers which form the structure of a competition. In a classical competition model conducted by Michael Porter, the role of business should effectively develop and implement the strategy to face the competitors, threats, or 'new player' in the marketing level.

Competition is perceived as a common thing in marketing level as long as it is positive. It is useful in encouraging the constant effort to take an advantage from a 
competitive market. The power of competition surely needs significant resources for the company continuity. There are five competitive strategies, namely cost leadership, differentiation strategy, innovation strategy, growth strategy, and strategic alliance. Information technology plays an important role in generating the business process. The ability to process the information from a computer substantially can improve the efficiency of the business process. Of course, it is followed by communication of the person in charge to operate the management.

The information system is designed to facilitate the administrator to manage the library management. The computerized-based system needs certain software to process the data. Thus, the administrator of the library can monitor the availability of the book list, returning, and borrowing. By employing this system, the administrator will not face the difficulty in reporting the record to the head of the library.

\section{Methode}

\subsection{Design of the study}

This study was conducted in the library at SMK Muhammadiyah 2 Malang. It applied survey approach by collecting, analyzing, interpreting the data which aimed at describing particular events at SMK Muhammadiyah 2 Malang.

\subsection{Population and sample}

The population was the library system of SMK Muhammadiyah 2 Malang. The observation aimed at investigating the library system by implementing a computerized-based system.

\subsection{Data collection}

The data were collected using direct documentation and interview with the library administrator at SMK Muhammadiyah 2 Malang 


\subsection{Definition of key terms}

The following definitions of key terms are based on the observed characteristics by describing the behavior or phenomena before justifying the fact. These indicators are used to analyze the library system at SMK Muhammadiyah 2 Malang.

1. Library

In this study, the researcher directly observed the condition of the library at SMK Muhammadiyah 2 Malang.

\section{System}

In this study, the researcher directly observed the system of borrowing and returning books conducted by SMK Muhammadiyah 2 Malang students.

\section{School}

In this study, the researcher examined whether the school has implemented new technology regarding the library system at SMK Muhammadiyah 2 Malang.

\section{Conclusions}

This chapter concerns the findings and discussion of the study. The findings cover the descriptive explanations related to the problems of the study. The discussion provides wide possibly argumentation towards the findings.

\subsection{Findings}

\subsubsection{General description of the schools}

SMK Muhammadiyah 2 Malang, known as SMK Muda, was established in 1979. It located in Jalan Baiduri Sepah 27 Tlogomas, Malang. The presence of this school aimed at answering the demands of the industrial world. It cannot be separated from a fundamental idea that SPG Muhammadiyah 1 (Teacher Education School) had a rumor to be closed. Hence, the Education and Culture Board of Muhammadiyah has decided to open a formal SMK (Vocational School) by involving the stakeholders of Muhammadiyah Organization. However, the problems faced by SMK Muhammadiyah 2 were still unknown yet by the local community and unidentified vision of the school graduates after graduation. These problems occurred due to the instability of economic 
development and market needs. Moreover, SMK Muhammadiyah 2 was badly perceived as a platform for students with vandalism.

The school infrastructures are categorized well, but they still require an improvement, especially in the library with the limited collection and manual-based system. An innovation is highly needed by the school board to 'juggle' manual system to be a computerized-based system (online).

\subsubsection{Data analysis}

According to data analysis conducted by the researcher, SMK Muhammadiyah 2 Malang is still implementing a manual-based system instead of the computerized-based system. Therefore, the development of information technology eases an operation system of borrowing and returning books.

\subsection{Discussion}

\subsubsection{Software development}

Software, commonly recognized as an application, device, or platform development, is a developed product related to computer programs, such as writing and coding activities. Shortly, the software has a function to facilitate human works by displaying them in a simple way.

The software can be developed for various purposes, such as fulfilling business needs (custom software), potential users (commercial software), and personal needs. Software development was embedded as a controller of consumer's products. Therefore, quality control is able to create software engineering aimed at implementing a systematical approach which is attached in a paradigm of developing process.

\subsubsection{Website-based library}

There are numerous applications for the information system of a library, such as PHP and MySQL. MySQL is a set of the device for database management system which is distributed freely under General Public License. Every user can enjoy the application and prohibited to sell it for personal or communal interests. This application helps the users to operate transactional and non-transactional data. However, it still lacks visual 
program support. Hence, the presence of this application will support the availability of the library management system at SMK Muhammadiyah 2 Malang.

\section{References}

[1] Laudon C. Kenneth. Sistem Informasi Manajemen Mengelola Perusahaan Digital. $13^{\text {th }}$ Edition. 2015. Salemba Empat. Jakarta

[2] Mc. Leod Raymond. 2008. Sistem Informasi Manajemen. 10 $0^{\text {th }}$ Edition. Salemba Empat. Jakarta

[3] O’Brien James, George M. Marakas. Sistem Informasi Manajemen. $9^{\text {th }}$ Edition. Book 2.2014. Salemba Empat. Jakarta

[4] O’Brien James, George M. Marakas. Sistem Informasi Manajemen. $16^{\text {th }}$ Edition. Buku 1. 2017. Salemba Empat. Jakarta

[5] Sianipar Eng. PHP dan MySQL Langkah demi Langkah. 2015. Andi Offset. Semarang

[6] Wahana Komputer. 2014. Microsoft Access 2013. Andi Offset. Semarang 